\title{
İş Arkadaşlarından ve Yönetimden Duyulan Tatminin Normatif Bağlılığa Etkisi: Kişilik Özelliklerinden Uyumluluğun Aracılık Rolü ${ }^{1}$
}

\author{
DOI: 10.26466/opus.590495 \\ * \\ $\underline{\text { Mustafa Bekmezci }}$ - İbrahim Sani Mert ${ }^{\star *}$ - Hakan Turgut ${ }^{\star * *}$ \\ * Doç. Dr. Toros Üniversitesi, Mersin / Türkiye \\ E-Posta: mustafa.bekmezci@toros.edu.tr ORCID: 0000-0002-1206-690X \\ ** Prof. Dr. Antalya Bilim Üniversitesi, Antalya / Türkiye \\ E-Posta: ibrahim.mert@antalya.edu.tr \\ ORCID: $0000-0002-2850-1865$ \\ *** Doç. Dr. Başkent Üniversitesi, Ankara / Türkiye \\ E-Posta: hturgut@baskent.edu.tr \\ ORCID: $\underline{0000-0002-4572-194 \mathrm{X}}$
}

Öz

Bu çalışmada, iş arkadaşlarından ve yönetimden duyulan tatminin normatif bağlllı̆̆a etkisinde kişilik özelliklerinden uyumlu kişilik özelliğinin aracılık etkisi araştırılmıştır. 228 özel hastane sağlık çalışanlarından anket yöntemi kullanılarak toplanan verinin nicel analizi sonucunda, iş arkadaşlarından tatmin ile normatif bağlllık arasında pozitif yönde ve anlamll; yönetimden duyulan tatmin ile normatif bağlllık arasında pozitif yönde ve anlamlı; iş arkadaşlarından tatmin ile uyumlu kişilik özelliği arasında pozitif yönde ve anlaml bir ilişki olduğu tespit edilmiştir. Kişilik özelliklerinden uyumluluk ile normatif bağlllık arasında ve yönetimden duyulan tatmin ile kişilik özelliklerinden uyumluluk arasında pozitif yönde ve anlamlı bir ilişki bulunamamıştır. Çalışmada beklenilenin aksine uyumlu kişilik özelliğinin, iş arkadaşlarından tatmin ve yönetimden duyulan tatminin normatif bağhllı̆̆a etkisinde aracı rolü olmadiğı tespit edilmiştir. Kurallara uyan, yardımsever ve insancıl olan bu kişilerin örgüte çok şey kazandıracağı muhakkaktır. Bu kişilerin performansının değerlendirilmesinde; diğer insanlara yardımcı olma, diğerlerinin gereksinimine öncelik verme gibi özellikleri dikkate alınmalı, bu özelliklerinden dolayı takdir edilmeli, katkıları görülmeli, özellikle maddi anlamda eşit imkânlar sağlanmalıdır.

Anahtar Kelimeler: Normatif Bağlllık, Uyumluluk, İş Arkadaşlarından Tatmin

\footnotetext{
${ }^{1}$ Bu çalışma, 18. Uluslararası İsletmecilik Kongresinde sözlü bildiri olarak sunulmuştur.
} 


\title{
The Effect of Relationship with Co-Workers and Quality of Supervision on Normative Commitment: The Mediating Role of Agreeableness Personality Trait
}

*

\begin{abstract}
In this study, the mediating role of agreeableness personality trait on the effect of relationship with coworkers and quality of supervision on normative commitment was investigated. The quantitative analysis of the data collected by survey method from 228 participants of private hospital workers showed that relationship with co-workers and normative commitment, quality of supervision and normative commitment, relationship with co-workers and agreeableness personality trait have a positive and significant relation. In contrast to the expectations, it was determined that agreeableness personality trait does not play an important role on the effect of relationship with co-workers and quality of supervision on normative commitment. It is certain that these people who follow the rules, helpful and humane, will contribute a lot to the organization. In assessing the performance of these people, characteristics such as assisting other people and giving priority to the needs of others should be considered. They should be appreciated for their characteristics; their contributions should be seen, and equal opportunities should be provided especially in financial terms.
\end{abstract}

Keywords: Normative Commitment, Agreeableness, Relationship with Co-Workers 


\section{Giriş}

Günümüzde, örgütlerin rekabet avantajı sağlaması için örgüte bağlı nitelikli insanlara sahip olması gerekmektedir. Çünkü örgüte bağlı kişilerin, örgüt değerlerini ve amaçlarını benimseyeceği, bunları hayata geçirmek için daha fazla çalışacağı öngörülmektedir. Nitekim örgüte bağlı kişilerin örgüt açısından olumlu davranışlar sergilediği yapılan görgül araştırmalarla da ortaya konmuştur. Çalışanlar, kendisini örgütle özdeşleştirdiği ve örgütten elde ettiklerini kaybetmekten korktuğu veya örgütte yaptıklar1nın doğru ve ahlaki olduklarına gönülden inandığı için örgüt üyeliğini devam ettirmek istemektedir. Bu kapsamda örgütler için çalışanların kendisini örgütle özdeşleştirmesini ve çalışanların örgüte bağlılığını devam ettirmesi çok büyük önem arz eder. Çünkü günümüzde personel devir oranı yüksek seviyede olan örgütlerin acımasız rekabet ortamında ayakta kalması mümkün görülmemektedir. İşletmelerin giderlerinin büyük kısmını personel giderleri oluşturmaktadır. Örgütsel bağlılığın kişilerin örgütle özdeşleşmesi üzerinde etkisi olduğu ve bunun sonucunda çalışanların daha az işten ayrıldığı sonucuna ulaşılmıştır (Çelik ve Yıldız, 2018). Örgütsel bağlılık üzerinde etkili olan kişisel, örgütsel ve örgüt dışı faktörler bulunmaktadır. Özellikle örgütsel faktörler kapsamında iş ortamı, iş arkadaşları ve yönetim örgütsel bağlılık kapsamında merkezi bir role sahiptir. Bu kapsamda yöneticilerin yönetim tarzı, kuralları uygulama şekli, adil davranıp davranmaması gibi hususlar ile iş arkadaşlarının tavır ve davranışları önemlidir. Yönetimden ve iş arkadaşlarından duyulan tatmin, çalışanların yönetici ve iş arkadaşlarına karşı şükran duygusunu ortaya çıkarmaktadır. Bu nedenle örgütte kalmayı ahlaki bir sorumluluk olarak görmelerine neden olmaktadır. Diğer taraftan, insan davranışlarının temel yapısını oluşturan kişiliğin, insanın olaylar karşısında nasıl tepki gösterdiği, diğer insanlarla nasıl bir etkileşim içinde olabileceği hususlarını kapsadığı öngörülmektedir.

Personel seçimi ve kariyer danışmanlığının genel amacı, bir kişinin özellikleri ile o kişinin nitelikleri arasında iyi bir uyum sağlamaktır. Uyumsuzluğun, zihinsel zorlanma ve işten ayrilmaya yol açan düşük iş tatmini ile sonuçlanması olasıdır. Buna göre, birçok bilim adamı ve uygulayıcı, kişilik değişkenlerinin çalışma koşullarına yönelik davranışsal tepkilerin öngörülmesindeki önemi üzerinde hemfikirdir (Jong vd., 2001, 
s.350). Beş faktörlü kişilik özellikleri modeli, endüstriyel örgütsel psikolojinin birçok alanında araştırılmış olmasına rağmen, bu modelin iş tatmini ile ilişkisi daha az çalışılmıştır (Judge vd., 2002, s.531). Bu kapsamda daha çok sevilen, daha çok işbirlikçi, sıcak ve güvenilir olarak tanımlanan uyumlu kişilik özelliğine sahip çalışanların yöneticilere ve iş arkadaşlarına karşı daha fazla şükran bağlılığına (normatif bağlılık) sahip olduğu söylenebilir. Bu çalışmada, iş arkadaşlarından ve yönetimden duyulan tatminin normatif bağl1lığa etkisinde uyumlu kişilik özelliğinin etkisi araştırılmıştır.

\section{Kavramsal çerçeve}

\section{İş tatmini}

Günümüzün rekabet şartları, çalışanların geçmişe göre daha etkin ve verimli olmalarını gerektirmektedir. Çalışanların; bilgisi ve tecrübeleri ile örgüte en üst seviyede katkı sağlaması, mevcut faaliyetlerin iyileştirilmesi ve geliştirilmesi için sürekli bir arayış içinde olması, gelecekle ilgili öngörülerde bulunması ve fikirlerini rahatlıkla ifade edebilmesi, örgütlerin varlıklarını sürdürebilmesi için önem arz etmektedir. Çalışanların işyerinde bu şekilde davranması; işine, işyerine, yönetime ve iş arkadaşlarına karşı gösterdiği tutum ile yakından ilgilidir. İnsan davranışlarının kaynağını oluşturan tutum, insanın karşılaşabileceği herhangi bir olay veya çeşitli durumlar karşısında olası bir tavır ve davranış tipi olarak tanımlanmaktadır (İnceoğlu, 2004, s.11). İnsanlar haz duyduğu, tatmin olduğu durumlar karşısında olumlu tavır ve davranışlar sergileyeceği düşünülmektedir. Bu nedenle iş ortamında bulunan personelin tatminini etkileyen unsurların da dikkatli bir şekilde ele alınması gerekmektedir. Bu kapsamda değerlendirilen iş tatmini de uzun yıllar ilgi uyandırmıştır. İş tatmini yönetim, psikoloji ve davranış bilimleri alanında hala çalışılan önemli konulardan biridir (Yang ve Wang, 2013, s.566; Özkalp ve Kırel, 2001, s.129; Ishfaq vd., 2011, s.228). Nitekim iş tatmininin iş performansı (Sullivan ve Baghat, 1992; Judge vd., 2001), örgütsel bağlllık (Porter vd., 1974; Agho vd., 1993), verimlilik (Miller ve Monge, 1986), örgütsel vatandaşlık davranış1 (Moorman, 1993), iyi olma hali (Freeborn, 1998), yaşam tatmini (Aşan ve Erenler, 2008), iş stresi (Sullivan ve Baghat, 1992), işten ayrılma niyeti 
(Fang, 2001; Çekmecelioğlu, 2005), işi sabote etme ve işten ayrılma (Dole ve Schroeder, 2001) gibi hem örgütü hem de çalışanların yaşam kalitesini olumlu veya olumsuz yönde etkileyen konularla yakın ilgisi bulunmaktadir.

İş tatmini, bireyin sahip olduğu işin özelliklerini değerlendirmesi ve bu değerlendirme neticesinde işi hakkında olumlu duygulara sahip olması (Robbins ve Judge, 2012, s.77) şeklinde tanımlanırken, bireyin işten elde ettiklerine karşı gösterdiği tepki (Gordon, 2011:191) şeklinde de tanımlanmaktadır. Birinci tanım iş tatminini duygusal bir tepki olarak (İşçan ve Timuroğlu, 2007, s.125), ikinci tanım da iş tatmini bir değerlendirme (Lim, 2008 , s.5) olarak ele almaktadır. Çetin ve Basım (2011, s.84), her iki yaklaşımı da dikkate almış; iş tatminini, çalışanın yapmakta olduğu işten aldığı ücret, çalışma koşulları, karşılıklı sosyal ilişkiler gibi çeşitli faktörlere ilişkin sahip olduğu olumlu duygusal bakış açısının bir sonucu olarak ortaya çıktığını belirtmiştir. Tella ve arkadaşları (2007, s.4)'na göre, iş tatmini, kişinin önem verdiği konulara, örgütün ne kadar önem verdiği algısının bir sonucudur. Bu tanımın doğal bir sonucu olarak, iş tatmini, kişisel ve örgütsel değerlerin birbiri ile uyumlu olması durumunda gerçekleştiğini söylenebilir. Bunun yanında hem iş ile ilgili tatminin sağlanması için gereken koşulları hazırlamak hem de örgüte olan bağlılı̆̆ı artıran çeşitli faaliyetleri düzenlemek ve yönetmek yöneticilerin en temel sorumluluğudur (Hatipoğlu ve Dündar, 2018, s.48).

İş tatmininin çok boyutlu bir yapıya sahip olduğu ifade edilmektedir (Ishfaq vd., 2011, s.228; Yılmaz, 2012, s.3). Nitekim Hodgetts (1991, s.88), iş tatminini ortaya çıaran temel faktörlerin kazanılan ücret ve işten elde edilen diğer faydalar, yükselme imkânları, liderlik ve işin kendisi ile içinde bulunulan çalışma grubu olduğunu belirtirken, Steers (1991, s.80), işin kendisi, yapılan ödemeler, işyerindeki yükselme fırsatları, nezaret ve çalışma yerindeki iş arkadaşları (Aktaran: Yeşil ve Dereli, 2012, s.109), İşçan ve Timuroğlu (2007, s.125), yapılan işin niteliği, kazanılan ücret, iş yerindeki terfi imkânları, çalışma şartları ve insani ilişkiler olduğunu ifade etmiştir. Friday ve Friday (2003, s.429-430), Crosman ve Abou-Zaki (2003, s.369), Savery (1996, s.19), Lam (1995, s.74) iş tatmini boyutlarının kazanılan ücret, iş terindeki güvenlik iklimi, terfi imkânları, liderlik, işyerindeki yönetim tarzı, mevcut çalışma koşulları, işyerindeki arkadaşlık ortamı, 
amirleri tarafından takdir edilme ve yapılan işin kendisi gibi faktörlerden meydana geldiğini ifade etmiştir (Aktaran: Erdil vd., 2004, s.19).

Yapılan araştırmalar neticesinde, iş tatmini boyutları arasında yer alan yönetim veya liderlik ile iş arkadaşları veya arkadaşlık ortamının merkezi konumda olduğu görülmektedir. Diğer bir anlatımla yöneticilerin çalışanlara karşı tutumu, kuralların ve talimatların uygulanma şekli ile sosyal bir varlık olan insanın faaliyetlerini gerçekleştirdiği, iletişim ve etkileşim içinde bulunduğu geniş anlamda örgütteki, dar anlamda kendi bölümünde veya departmanında bulunan iş arkadaşları, iş tatminini etkilemektedir. Bir çalışanın, sonuçta iş tatminine yol açan iş arkadaşı desteği ile bağlılık hakkındaki algısı arasında anlamlı bir ilişki vardır (Attiq vd., 2017, s.252). Ayrıca, iş tatminsizliğinin işten ayrılma niyeti, işi sabote etme, devamsızlık ve işten ayrılma gibi sonuçlarının olduğu değerlendirildiğinde, beşerî ilişkilerden, yani hem yöneticilerden hem de iş arkadaşlarından tatmin olmanın, yine bu kişilerin işgörene yönelik tavır ve davranışlarından kaynaklanan; işgörene işten ayrılmanın doğru bir hareket olmadığını düşündüren, diğer çalışanlara karşı kendisini sorumlu hissetmesini sağlayan normatif bağlılığını artıracağı değerlendirilebilir. Nitekim, Oshagbemi (2000), akademisyenler üzerinde yaptığı araştırma neticesinde; çalışma arkadaşlarının davranışları ile iş tatmini arasında pozitif yönde ve anlamlı bir ilişki olduğunu tespit etmiştir.

\section{Kişilik}

Kişilik, bireyin ilişkide olduğu diğer bireylere tepki göstermek veya onlarla karşılıklı etkileşime girmek için kullandığı yollardır ve bu da bireyin sergilediği ölçülebilir kişilik özellikleri çerçevesinde tanımlanmaktadır (Robbins ve Judge, 2012, s.135). Kişilik özellikleri, kişinin davranışlarının ve farklı durumlar karşısında nasıl davranacağı konusunda diğer kişilerin tahmininin dayanağını oluşturan görece değişmez nitelikteki kişiye has özelliklerdir (Tabak vd., 2012, s.58).

Kişilik konusunda pek çok araştırma yapılmış, insan kişiliğindeki belirli farklılıkların çoğunu kapsayan beş faktör kişilik modeli (Digman, 1989), günümüz bilim dünyasında yaygın olarak kabul görmüştür (Panaccio ve Vandenberghe, 2012, s.647). Model beş boyuttan oluşmaktadır. 
Bunlar; dışadönüklük, duygusal tutarlılık, sorumluluk, uyumluluk ve gelişime açıklık olarak belirlenmiştir (Robbins ve Judge, 2012, s.138; Panaccio ve Vandenberghe, 2012; Bono ve Judge, 2004; Hogan ve Kaiser, 2005). Dışadönüklük boyutu, sosyallik, hırs, coşku, enerjik olmak gibi olumlu duygularla ilgilidir. Dışadönük kişiler; sokulgan, kendini ifade edebilen, iyimser, dikkat çekmeyi seven sosyal kişilerdir. Dışadönük olmayan kişiler ise ölçülü, çekingen, mesafeli, korkak, sessiz, yalnız çalışmaktan hoşlanan, kendi halinde bireylerdir. Duygusal tutarlılık boyutu, kişinin gerilime dayanma durumu ile ilgilidir. Olumlu duygusal kararlılığa sahip bireyler sakin, kendinden emin, özsaygısı yüksek, görüşlerini savunma cesaretine sahip kişilerdir. Olumsuz duygusal kararlılığa sahip kişiler; sinirli, endişeli, karamsar, savunmacı ve kendine güveni olmayan kişilerdir. Sorumlu kişiler, düzenli, titiz, güvenilir ve azimlidir; başarma güdüsüne sahiptir, kural ve prosedürlere uygun hareket eder. Bu boyutta düşük puan alan kişiler ise dikkati kolayca dağılabilen, genellikle amacı olmayan, düzensiz, çoğu zaman vurdumduymaz ve güvenilir olmayan kişilerdir. Uyumluluk boyutu, bireyin diğer bireylere uyma, insancl ve şefkatli olması ile ilgilidir. Yüksek seviyede uyum gösteren bireyler işbirlikçi, sıcakkanlı ve güvenilir, diğerlerinin gereksinimlerini karşılamaya odaklı kişilerdir. Uyumluluk konusunda düşük puan alan bireyler ise soğuk, uyumsuz, kaba ve muhaliftir. Gelişime veya deneyime açıklık boyutu, gelenekselliğe karşı, yeniliğe ilgi duyma ile ilgilidir. Yeniliğe açık bireyler, yaratıcı ve meraklı, hayal gücü yüksek ve farklı düşünen kişilerdir. Yeniliğe veya deneyime kapalı bireyler ise geleneklere bağlı muhafazakâr, ilgi alanı dar, değişikliği sevmeyen kişilerdir.

Büyük beş üzerinde yapılan araştırmalarda, bu modeldeki kişilik boyutları ile iş yerindeki davranışlar arasında da ilişkiler bulunmuştur (Robbins ve Judge, 2012, s.138-140). Dışadönük kişiler, işlerinde ve genel olarak yaşamlarında daha mutlu olma, kişilerarası etkileşim gerektiren işlerde daha iyi performans gösterme eğilimindedir. Duygusal tutarlılık, yaşam tatmini, iş tatmini ve düşük stres miktarı ile doğrudan ilgilidir. Duygusal tutarlılık puanı düşük kişiler, aşırı tedbirli davranan kişiler oldukları gibi ve özellikle stresin fiziksel ve psikolojik etkilerine karşı savunmasız olan kişilerdir. Sorumluluk puanı yüksek kişiler, yüksek iş performansına sahip olma eğilimi gösterir. Uyumlu kişiler, uyumsuz bireylere nazaran daha mutludur, daha çok sevilir, daha işbirlikçidir, kurallara uyar. Ancak 
uyumlu kişiler, kariyer basamaklarında özellikle de kazanç açısından alt seviyelerde kalma ile ilişkilendirilmektedir. Gelişime açık kişiler, organizasyonda meydana gelen değişimlerle daha kolay baş edebilir ve gerektiğinde değişen ortamlara daha kolay bir şekilde uyum gösterebilir. Son olarak yapılan bir araştırmada otel işletmelerinde çalışan işgörenlerin beş faktör kişilik özelliklerinin iş tatmini ve örgütsel bağlllık üzerinde etkili olduğu sonucuna ulaşılmıştır (Aslan ve Kılıçlar, 2018).

\section{Örgütsel Bă̆lılık}

Örgütsel bağl1lık, işgörenin kendisini dâhil olduğu örgütün amaçları ile özdeşleştirmesi, örgütün sahip olduğu özellikleri içselleştirmesidir; ayrıca örgütsel bakış açısına kişinin uyum gösterme derecesi olarak da tanımlanabilir (McDonald ve Makin, 2000, s.86). Diğer bir anlatımla örgütsel bağlılık, çalışanın iş yerine psikolojik olarak bağlanması, örgütte kalma ve örgüt için çaba gösterme arzusu ile örgütün amaç ve değerlerini benimsemesidir (Doğan ve Kılıç, 2007, s.39). Örgütsel bağlılığın üç karakteristik unsuru vardır (Richards vd., 1994): Örgütün değerlerini ve amaçlarını kabul etmek ve bunlara karşı yüksek seviyede bir inanç duymak, örgüt yararına çoğunlukla beklenenden daha fazla çaba sarf etmek konusunda gönüllü olmak ve örgüt üyeliğini sürdürmek ile ilgili çok güçlü bir istek duymak.

Meyer ve Allen (1991, s.67), örgütsel bağlılığ1; duygusal (affective), devam (continuence) ve normatif (normative) bağll1ık olmak üzere üç grupta ele almıştır. Bu sınıflandırma, günümüzde de örgütsel bağlılıkla ilgili çalışmalarda temel olarak alınmaktadır (Doğan ve Kılıç, 2007, s.44). Duygusal bağlılık, çalışanın örgütle özdeşleşmesi, kendisini örgütün bir parçası olarak görmesi neticesinde örgüte ait amaç ve değerleri kabul ederek örgüt yararına olağanüstü çaba göstermesidir. Devam bağlılı̆̆ı, çalışanın örgütte elde ettiği kazanımları örgütten ayrılması durumunda kaybedeceği düşüncesiyle örgüt üyeliğini sürdürmesidir. Normatif bağlılık, çalışanın örgütte yaptıklarının doğru ve ahlaki olduğuna inanmasının bir neticesi olarak örgütte kalmayı bir zorunluluk olarak görmesidir.

Örgütsel bağlılığı etkileyen faktörler yazındaki genel kullanım doğrultusunda; kişisel faktörler, örgütsel faktörler ve örgüt dışı faktörler olmak 
üzere üç ayrı başlık altında ele alınmaktadır (İnce ve Gül, 2005, s.59). Kişisel faktörlerin kapsamında; çalışanların işten beklentileri, psikolojik sözleşme ve çalışanların kişisel özelikleri gibi konular ele alınmaktadır. Çalışanların örgütsel bağlılığı üzerinde etkili olan örgütsel faktörler; işin sahip olduğu nitelik ve önemi, işletmede gösterilen yönetim tarzl, çalışanların karar alma süreçlerine katılma durumu, iş grupları, örgüte ait kültür, rol çatışması, astların gösterdiği beceri düzeyi, işe odaklanma, yapılan görevin kimliği ve işletme içerisinde uygulanan örgütsel ödüller gibi değiş̧kenlerdir. Ayrıca örgütsel faktör olarak rol belirsizliği, yapılan işlerin güçlüğü, işyerinde ast-üst ilişkileri, örgüt içerisindeki ilerleme ve kariyer olanakları, işletme tarafından çalışan bireyin ihtiyaçlarına önem verme, çalışanlar arasında ödeme eşitliği ve denetim ilişkilerinden de bahsedilebilir.

Kişinin örgüte bağlılığı ile ilişkili olan örgüt dişı faktörler ise sektörde yeni iş bulma olanakları, profesyonellik, sektörün genel durumu, ülkenin sosyo-ekonomik durumu ve ülkedeki işsizlik oranı gibi faktörlerdir. Luthans (2005), örgütsel bağlllık kavramının, gösterilen yüksek iş performansı, düşük iş bırakma oranı ve düşük işe devamsızlık gibi kritik iş davranışlarıyla yakın ilişki içerisinde bulunmasından dolayı, yapılan çalışmalardaki öneminin arttığını belirtmektedir. Ampirik çalışmalar da örgütsel bağlılı̆̆ın iş performansı, pazar yönelimi, örgütsel vatandaşlık davranışı, örgütsel değişim faaliyetlerine katılma gibi örgüt tarafından arzu edilen davranışlarla pozitif yönlü; işten ayrılma niyeti, devamsızlık gibi örgüt tarafından arzu edilmeyen üretim karşıtı tutum ve davranışlarla negatif yönlü bir ilişkisi olduğunu göstermektedir (Limpanitgul vd., 2014, s.100). Wasti (2003), kültürler bazında incelediği örgütsel bağlılığı, bireyci değerleri benimsemiş olan çalışanlara kıyasla daha toplulukçu olan Türk çal1şanların örgütsel bağlılıkla yakından ilişkili olan işten ayrılma niyetini normatif bağlılığın daha güçlü yordadığını göstermiştir.

İş tatmini ile örgütsel bağlılığın karşılıklı ilişki içinde bulunduğu ifade edilmekle birlikte, literatürdeki baskın görüş, iş tatmininin örgütsel bağl1lığ 1 artırdığ 1 yönündedir (Sığrı ve Basım, 2006, s.132). Yöneticinin işgörene, işgörenin işine yönelik teknik ve psikolojik yönden yardımcı olması (Sığrı ve Basım, 2006, s.136), iş arkadaşlarının birbirine yardımcı olmasının, aralarındaki olumlu ilişkilerin, ihtiyaç durumunda birbirini korumasının iş tatminini artıracağı ifade edilmektedir (Sığrı ve Basım, 2006, s.137). 
Hoş ve Oksay (2015), hemşirelerde örgütsel bağlllık ve iş tatmini arasındaki ilişkiyi araştırmış, iş tatminini içsel ve dışsal olmak üzere iki alt boyutta ele almıştır. Ölçeğin dışsal alt boyutu, yöneticinin idare tarzı, karar verme yeteneği, işgöreni takdir etmesi gibi yönetici davranışları ile ücret terfi olanağı, çalışma koşulları, işin işgöreni her zaman meşgul etmesi ve çalışma arkadaşlarının birbiri ile anlaşması hususlarını değerlendiren maddelerden oluşmaktadır. Hoş ve Oksay (2015), iş arkadaşlarından ve yönetimden tatmin ile normatif bağlılık arasında anlamlı ve pozitif yönlü bir ilişki tespit etmiştir.

Recepoğlu ve arkadaşları (2013) ile Bulut (2017), akademisyenler üzerinde yaptığı araştırma sonucunda, uyumluluk kişilik özelliği ile örgütsel bağlılık arasında anlamlı ve pozitif yönlü bir ilişki tespit etmiştir. Bir kamu hastanesinde yapılan araştırma neticesinde de uyumluluk kişilik özelliğinin örgütsel bağlllığın önemli bir belirleyicisi olduğu görülmüştür (Ocak vd., 2017). Doğar ve Gürsoy (2017) ise banka çalışanlarına yönelik yaptığ 1 çalışma neticesinde uyumluluk kişilik özelliğinin normatif bağlılığı istatistiksel olarak etkilemediğini belirlemiştir.

Judge ve arkadaşları (2002), kişilik ve iş tatmini arasındaki ilişkiyi ortaya koymuş, uyumluluk kişilik özelliği ile iş tatmini ilişkisinde aynı yönlü nispeten zayıf bir ilişki elde etmiştir. Yine Demir (2012), üniversitede çalışan idari ve sözleşmeli personel üzerinde yaptığı analiz neticesinde iş tatmini ve uyumluluk kişilik özelliği arasında pozitif yönlü, anlamlı ama zayıf bir ilişki olduğunu belirlemiştir.

Bu bilgilerden yola çıkarak, iş arkadaşlarından ve yönetimden duyulan tatminin örgütsel bağlılığı artıracağı, bu bağllı̆̆ın da Allen ve Meyer (1990) tarafından öngörülen örgütsel bağlılık boyutlarından normatif bağlılıktan kaynaklanabileceği söylenebilir. İş arkadaşlarıyla ve yönetimle işbirlikçi davranışlar sergileyen, kurallara daha çok uyan, sıcak ve güvenilir uyumlu kişilik özelliğine sahip çalışanların bu bağlılık türünü daha çok sergileyeceği düşünülmektedir. Bu kapsamda; bu çalışmada, iş arkadaşlarından ve yönetimden duyulan tatminin normatif bağlılığa etkisinde uyumlu kişilik özelliğinin etkisi araştırılmıştır. Yapılan literatür araştırmasında uyumluluk kişilik özelliğinin bu kapsamda etkisi ile ilgili bir çalışmaya rastlanmamıştır. Araştırmanın modeli, Şekil 1'de gösterilmiştir. Araştırmanın hipotezleri ise bir sonraki sayfada sunulmuştur. 


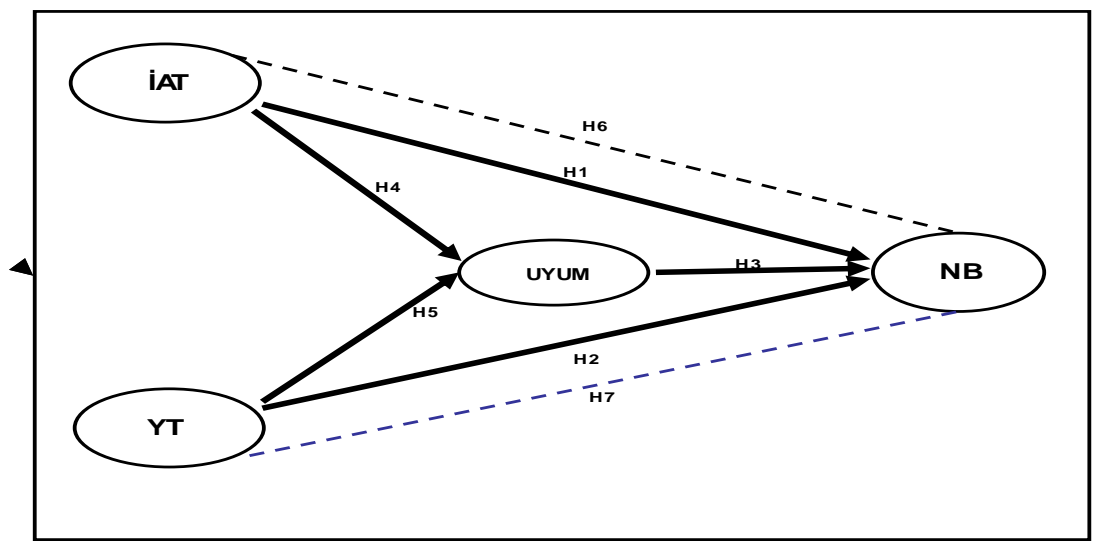

Şekil 1. Araştırma Modeli

- H1: İş arkadaşlarından tatmin olma ile normatif bağlılık arasında pozitif yönlü ve anlamlı bir ilişki bulunmaktadır.

- $\mathrm{H}_{2}$ : Yönetimden duyulan tatmin ile normatif bağlllik arasında pozitif yönlü ve anlamlı bir ilişki bulunmaktadır.

- H3: Kişilik özelliklerinden uyumluluk ile normatif bağlılık arasında pozitif yönde ve anlamlı bir ilişki bulunmaktadır.

- $\mathrm{H}_{4}$ : İş arkadaşlarından tatmin ile kişilik özelliklerinden uyumluluk arasında pozitif yönde ve anlamlı bir ilişki bulunmaktadır.

- Hs: Yönetimden duyulan tatmin ile kişilik özelliklerinden uyumluluk arasında pozitif yönde ve anlamlı bir ilişki bulunmaktadır

- H6: İş arkadaşlarından tatminin normatif bağlılığa etkisinde kişilik özelliklerinden uyumluluğun aracılık rolü vardır.

- H7: Yönetimden duyulan tatminin normatif bağlllığa etkisinde kişilik özelliklerinden uyumluluğun aracılık rolü vardır.

\section{Araştırmanın Yöntemi}

İş arkadaşlarından tatmin (İAT) ile yöneticilerden tatmin (YT)'in normatif bağlllığa (NB) etkisi ve bu etkide kişilik özelliklerinden uyumluluk (UYUM)'un aracılık rolünü ortaya çıarmak amacıyla yapılan bu araştır- 
mada; örneklem ve ölçekler hakkında kısaca bilgi verildikten sonra, oluşturulan modele ilişkin istatistiki analizler yapılmıştır. Bu kapsamda modelde yer alan her bir değişken için keşfedici (KFA) ve doğrulayıc faktör analizi (DFA) yapılmış, değişkenler arasındaki korelasyonlar tespit edilmiş, müteakiben hipotezler hiyerarşik regresyon analizi ile test edilmiştir. Yapılan bu analizlerin sonucunda elde edilen bulgular hakkında yönetici ve araştırmacılara ileride yapılacak çalışmalar için önerilerde bulunulmuştur.

\section{Araştırmanın Örneklemi}

Araştırma evrenini Mersin'de hizmet veren özel hastane çalışanları oluşturmaktadır. Örneklem büyüklüğü yaklaşık olarak 3000 kişidir. Ana kütleden $\% 95$ güvenilirlik seviyesi içerisinde $\% 5$ lik bir hata payı kabul edilerek örneklemin büyüklüğü 224 kişi olarak hesaplanmıştır (Sekaran, 1992, s.253). Çalışmamızda kümelere göre örnekleme yöntemiyle tesadüfi olarak tespit edilen toplam 350 kişiye anket dağıtılmıştır. Çalışanlara gönderilen anketlerden 243 'ü geri dönmüş, 228'inin analiz yapmak için uygun olduğu tespit edilmiştir.

Araştırmaya katılanların \%22,8'i kadın (n=52), \%48,2'si (n=118) evlidir. İşgörenlerin \%7'si (n=16) ortaokul, \%16,2'si (n=37) lise, \%11'i ön lisans $(n=25), \% 50$ 'si ( $n=114)$ üniversite, \%16'sı $(n=36)$ de lisansüstü ve üstü eğitim derecesine sahiptir. Örneklemin, \%16,67'si (n=38) 18-24 yaş, \%39,4'ü $(\mathrm{n}=90)$ 25-32 yaş, \%28,5'i (n=65) 33-40 yaş ve \%15,3'i de $(\mathrm{n}=35) 41$ ve yukarı yaşlar arasındadır. Çalışanların \%39,4'ü (n=90) 3 yıldan az, \%22,3’ü (n=51) 4-9 yıl arası, \%20,1'i (n=46) 10-15 yıl arası, \%14,4'ü (n=33) 16-21 yıl arası ve $\% 3,5^{\prime} i$ (n=8) de 22 ve yukarı yıl iş tecrübesine sahip olduğu görülmüştür.

\section{Araştırmanın Ölçekleri}

Araştırmada kullanılan ölçeklerle ilgili bilgiler aşağıda verilmiştir.

İş Arkadaşlarından ve Yönetimden Tatmin Ölçeği: Çalışanların iş arkadaşlarından ve yönetimden tatminini ölçmek amacıyla Schneider ve Dachler (1978) tarafından ortaya konulan ve 21 soru ile beş boyuttan (işin 
kendisi, ücret, terfi imkânı, yönetimden ve iş arkadaşlarından tatmin) oluşan ölçek kullanılmıştır. Ölçek, 7'li Likert tarzı bir ölçektir (1=Kesinlikle Katılmıyorum, 4=Fikrim Yok, 7=Tamamen Katılıyorum). Ölçeğin geçerlik ve güvenilirlik yönünden oldukça tutarlı olduğu rapor edilmiştir. İş tatmini ölçeğinin Türkçe geçerlemesi, Ergin (1997) tarafından yapılmıştır. Bu ölçeğin iş arkadaşlarından tatmin ve yönetimden tatmin boyutu kullanılmıştır. İş arkadaşlarından tatmin ve yönetimden tatmin alt boyutları dörder sorudan oluşmaktadır. İş arkadaşlarından duyulan tatmin ve yönetimden duyulan tatmin alt boyutlarının yapı geçerliliğini ölçmek için KFA ve DFA analizi, güvenilirliği ölçmek için güvenilirlik analizi yapılmıştır. İş arkadaşlarından tatmin ölçeğinin KFA analizi neticesinde; KMO örneklem yeterlilik değeri .83 ve örneklem büyüklük miktarının faktör analizi için yeterli özellikte olduğu görülmüştür $\left(\chi^{2}(228)=512,505, p<.01\right)$. İşarkadaşlarından duyulan tatmin ölçeğinin tek boyutlu yapısı doğrulanmış, faktör yüklerinin .84 ile .90 arasında olduğu görülmüştür. Yönetimden duyulan tatmin ölçeğinin KFA analizi neticesinde; KMO örneklem yeterlilik değeri .85 ve örneklem büyüklüğünün faktör analizi için yeterli miktarda olduğu tespit edilmiştir $\left(\chi^{2}(228)=659,923, p<.01\right)$. Yönetimden duyulan tatmin ölçeğinin tek boyutlu yapısı doğrulanmış, faktör yüklerinin .80 ile .83 arasında olduğu görülmüştür. DFA neticesinde; verilerin ölçeklerin tek faktörlü yapısına uyum sağladığı belirlenmiştir. İş arkadaşlarından ve yönetimden tatmin ölçeklerinin uyum iyilik değerlerinin kabul edilebilir sınırlar içinde olduğu görülmüştür. İş arkadaşlarından tatmin ölçeği için bu değerler (CMIN/df=1,86; GFI= .99; $\mathrm{CFI}=.99$; RMSEA= .06), yönetimden duyulan tatmin ölçeği için bu değerler $(\mathrm{CMIN} / \mathrm{df}=2,39$; $\mathrm{GFI}=.99 ; \mathrm{CFI}=.99$; RMSEA= .07) olarak hesaplanmıştır. Güvenilirlik analizi neticesinde, iş arkadaşlarından tatmin ölçeğinin Cronbach alfa değeri .89, yönetimden duyulan tatmin ölçeğinin Cronbach alfa değeri .92 olarak hesaplanmıştır.

Uyumluluk Kişilik Özelliği Ölçeği: Bir kişilik özelliği olan uyumluluğu ölçmek için Lewis R. Goldberg (1992) tarafından geliştirilen ve kişiliğin beş temel özelliği (dişadönüklük, duygusal tutarlılık, sorumluluk, uyumluluk ve gelişime açılık)'ni içeren ve her faktöründe 10, toplamda 50 sorudan oluşan büyük beş kişilik ölçeğinin "uyumluluk" boyutu kullanılmıştır. Ölçek 5'li Likert tarzı bir ölçektir (1=Hiç uygun değil, 5=Çok uy- 
gun). Ölçeğin Türkçe geçerlemesi Tatar (2017) tarafından yapılmıştır. Tatar (2017), test faktörlerinin asıl uygulamada .652 ile .794 arasında, tekrar test uygulamasında .670 ile .809 arasında iç tutarlılık gösterdiğini belirtmiştir. Bu ölçeğin uyumluluk kişilik özelliği alt boyutu kullanılmıştır. Ölçeğin yapı geçerliliğini ölçmek için KFA ve DFA analizi, güvenilirliğini ölçmek için güvenilirlik analizi yapılmıştır. KFA analizi neticesinde; KMO örneklem yeterlilik değeri .84 ve örneklem büyüklüğünün faktör analizi için yeterli büyüklükte olduğu tespit edilmiştir $\left(\chi^{2}(228)=580,249, p<.01\right)$. Ölçeğin tek boyutlu yapısı doğrulanmış, faktör yüklerinin . 47 ile .74 arasında olduğu görülmüştür. DFA neticesinde; verilerin ölçeğin tek faktörlü yap1sına uyum sağladığı belirlenmiştir. Ölçeğin uyum iyilik değerlerinin kabul edilebilir sınırlar içinde olduğu görülmüştür (CMIN/df=1,34; GFI= .96; $\mathrm{CFI}=$.97; RMSEA= .04). Güvenilirlik analizi neticesinde Cronbach alfa değeri .81 olarak hesaplanmıştır.

Normatif Bağhlık Ölçeği: Çalışanların normatif bağlılığını ölçmek için Meyer, Allen ve Smith (1993) tarafından oluşturulan, üç boyutlu örgütsel bağlılık ölçeği kullanılmıştır. Örgütsel bağlılık ölçeği 18 sorudan oluşmaktadır. Ölçek 5'li Likert tarzı bir ölçektir (1=Kesinlikle Katılmıyorum, 5=Tamamen Katılıyorum). Örgütsel bağlılık ölçeğinin Türkçe geçerlemesi Wasti (2000) tarafından yapılmıştır. Wasti (2000), ölçeğin Türk çalışanlarına uygunluğunu 351 kamu çalışanı ve 916 özel sektör çalışanı üzerinde araştırmıştır. 6 sorudan oluşan normatif bağlılık alt boyutunun yapı geçerliliğini ölçmek için KFA ve DFA analizi, güvenilirliğini ölçmek için güvenilirlik analizi yapılmıştır. KFA analizi neticesinde; KMO örneklem yeterlilik değeri .85 ve örneklem büyüklügünün faktör analizi için yeterli seviyede olduğu tespit edilmiştir $\left(\chi^{2}(228)=488,043, p<.01\right)$. Kullanılan ölçeğin tek boyutlu yapısı doğrulanmış, faktör yüklerinin .76 ile .84 arasında olduğu tespit edilmiştir. DFA neticesinde; verilerin ölçeğin tek faktörlü yapısına uyum gösterdiği gözlemlenmiştir. Ölçeğin uyum iyilik değerlerinin kabul edilebilir sınırlar içinde olduğu görülmüştür $(\mathrm{CMIN} / \mathrm{df}=2,77$; GFI= .97; CFI= .98; RMSEA= .08). Güvenilirlik analizi neticesinde Cronbach alfa değeri .85 olarak hesaplanmıştır. 


\section{Bulgular}

Analizler SPSS 21 programı ile yapılmıştır. Verilere ilişkin ortalama, standart sapma ve korelasyon değerleri Tablo.1'de gösterilmiştir.

Tablo 1. Verilere İlişkin Ortalama, Standart Sapma ve Korelasyon Değerleri

\begin{tabular}{lllllll}
\hline & Ort. & s.s. & $\mathbf{1}$ & $\mathbf{2}$ & $\mathbf{3}$ & $\mathbf{4}$ \\
\hline $\begin{array}{l}\text { 1.İs Arkadaşlarından } \\
\text { Tatmin (İAT) }\end{array}$ & 5,42 & 1,24 & $(.89)$ & & & \\
\hline 2.Yönetimden Tatmin (YT) & 4,68 & 1,66 & $.59^{* *}$ & $(.92)$ & & \\
\hline $\begin{array}{l}\text { 3.Uyumluluk Kişilik } \\
\text { Özelliği (UYUM) }\end{array}$ & 3,99 & 0,52 & $.22^{* *}$ & .07 & $(.76)$ & \\
\hline 4.Normatif Bağlllı̆̆ı (NB) & 3,33 & 0,97 & $.39^{* *}$ & $.52^{* *}$ & .06 & $(.85)$ \\
\hline
\end{tabular}

${ }^{*} p<.05,{ }^{* *} p<.01$

Tablo 1'de; İAT ile YT, İAT ile UYUM, İAT ile NB, YT ile NB arasında anlamlı bir ilişki olduğu; YT ile UYUM ve UYUM ile NB arasında ise anlamlı bir ilişki bulunmadığı görülmektedir.

Aracılık rolünü tespit etmek için Baron ve Kenny (1986), tarafından geliştirilen üç aşamalı regresyon analizi yapılmıştır. İş arkadaşlarından tatmin ile yönetimden tatmin, kişilik özelliklerinden uyumluluk ve normatif bağllıı arasındaki ilişkileri tespit etmek için iki ayrı hiyerarşik regresyon analizi yapılmıştır. Analiz sonuçları Tablo 2'de verilmiştir.

Aracı değişken olarak değerlendirilen uyumluluk kişilik özelliğinin bağımsız değişken olarak alınan iş arkadaşlarından tatmin ile bağımlı değişken olarak alınan normatif bağlılık arasında; Baron ve Kenny (1986) tarafından önerildiği şekilde (1) Bağımsız değişkenin (iş arkadaşlarından tatmin) ile aracı değişken (Uyum) üzerinde bir etkisi olduğu $(\beta=.221$; p<.01), (2) Bağımsız değişkenin (İş arkadaşlarından tatmin) bağımlı değiş̧ken (Normatif bağlılık) üzerinde bir etkisinin olduğu $(\beta=.400 ; p<.01)$ ve (3) Aracı değişken (Uyum) ikinci adımda regresyona dahil edildiğinde bağımsız değişkenin bağımlı değişken regresyon katsayısının $\beta=.400$ $(\mathrm{p}<.01)^{\prime}$ den $\beta=.394$ ( $\left.\mathrm{p}<.01\right)^{\prime}$ e düştüğü, ancak aracı değişkenin bağımlı değişken üzerinde etkisi olmadığı ( $\beta=.078 ; p>.05)$ tespit edilmiştir. Bu bulgular uyumluluk kişilik özelliğinin iş arkadaşlarından tatmin ile normatif bağlılık arasında bir aracılık etkisinin bulunmadığını göstermektedir. 
Tablo 2: Regresyon Analizi Sonuçları ( $n=228)$

\begin{tabular}{|c|c|c|c|c|c|c|}
\hline \multirow[t]{2}{*}{ İLİŞKİLER } & \multicolumn{2}{|c|}{ MODEL 1} & \multicolumn{2}{|c|}{ MODEL 2} & \multicolumn{2}{|c|}{ MODEL 3} \\
\hline & $\beta$ & $t$ & $\beta$ & $t$ & $\beta$ & $t$ \\
\hline$\dot{\mathrm{I}} \mathrm{AT} \rightarrow \mathrm{NB}$ & $.400^{* *}$ & 6,560 & & & $.394^{* *}$ & 6,287 \\
\hline İAT $\rightarrow$ UYUM & & & $.221^{* *}$ & 3,406 & & \\
\hline $\mathrm{UYUM} \rightarrow \mathrm{NB}$ & & & & & .115 & 1,745 \\
\hline $\mathrm{R}^{2}$ & .160 & & .049 & & .013 & \\
\hline$\Delta \mathrm{R}^{2}$ & .156 & & .045 & & .009 & \\
\hline $\mathrm{F}$ & $43,037^{* *}$ & & $11,603^{* *}$ & & 3,045 & \\
\hline $\mathrm{YT} \rightarrow \mathrm{NB}$ & $.515^{* *}$ & 9,022 & & & $.509^{* *}$ & 8,916 \\
\hline YT $\rightarrow$ UYUM & & & .073 & 1,093 & & \\
\hline $\mathrm{UYUM} \rightarrow \mathrm{NB}$ & & & & & .115 & 1,745 \\
\hline $\mathrm{R}^{2}$ & .265 & & .005 & & .271 & \\
\hline$\Delta \mathrm{R}^{2}$ & .262 & & .001 & & .264 & \\
\hline $\mathrm{F}$ & $81,393^{* *}$ & & 1,194 & & $41,800^{* *}$ & \\
\hline
\end{tabular}

Benzer şekilde (1) Bağımsız değişken (yönetimden duyulan tatmin) ile aracı değişken (Uyum) üzerinde bir etkisinin bulunmadığ $(\beta=.073 ; p>.05)$, (2) Bağımsız değişkenin (Yönetimden duyulan tatmin) bağımlı değişken (Normatif bağ lılık) üzerinde bir etkisinin olduğu $(\beta=.515 ; \mathrm{p}<.01)$, (3) Arac1 değişken (Uyum) ikinci adımda regresyona dahil edildiğinde bağımsız değişkenin bağımlı değişken regresyon katsayısının $\beta=.515(\mathrm{p}<.01)^{\prime}$ den $\beta=.509$ ( $\mathrm{p}<.01)^{\prime}$ a düştüğü, aracı değişkenin bağımlı değişken üzerinde bir etkisinin bulunmadığ1 $(\beta=.078 ; p>.05)$ tespit edilmiştir. Bu bulgular, uyumluluk kişilik özelliğinin yönetimden tatmin ile normatif bağlllık arasinda bir aracılık etkisinin bulunmadığını göstermektedir.

Elde edilen bu sonuçlar neticesinde; $\mathrm{H}_{1}, \mathrm{H}_{2}, \mathrm{H}_{4}$ hipotezleri kabul edilmiş, $\mathrm{H}_{3}, \mathrm{H}_{5}, \mathrm{H}_{6}$ ve $\mathrm{H}_{7}$ hipotezleri reddedilmiştir.

\section{Tartışma ve Sonuç}

$\mathrm{Bu}$ çalışmada iş arkadaşlarından ve yönetimden duyulan tatminin, normatif bağl1lı̆̆ına etkisi ve bu etkide kişilik özelliklerinden uyumluluğun aracılık rolünü tespit etmek için Mersin'de faaliyet gösteren özel hastane çalışanları üzerinde uygulamalı bir araştırma yapılmıştır. 
Araştırma sonuçları incelendiğinde; iş arkadaşlarından tatmin ile normatif bağlllık arasında pozitif yönlü ve anlamlı; yönetimden duyulan tatmin ile normatif bağlılı̆̆ı arasında pozitif yönlü ve anlamlı; uyumlu kişilik özelliği ile iş arkadaşlarından tatmin arasında pozitif ve anlamlı bir ilişki tespit edilmiş, beklenilenin aksine uyumlu kişilik özelliğinin iş arkadaşlarından tatmin ile yönetimden duyulan tatmininde normatif bağlllı̆̆ın aracı rolü olmadığı tespit edilmiştir.

Yapılan araştırmalarda, iş tatmini ile örgütsel bağlılık arasında pozitif ve anlamlı ilişkilerin bulunduğu ortaya konmuştur (Porter vd., 1974; Mcdonald ve Makin, 2000; Tella vd., 2007). İş arkadaşlarından tatmin ve yönetimden duyulan tatmin de iş tatmininin alt boyutlarıdır. Dolayısıyla iş arkadaşlarından tatmin ile yönetimden duyulan tatminin normatif bağlılığ pozitif yönde etkilemesi beklenen bir sonuçtur ve araştırmanın neticesinde de bu sonuç elde edilmiştir.

Literatürde uyumluluk kişilik özelliğine sahip kişilerin, yardımsever, güvenilir, insancıl ve şefkatli, başkalarını düşünen, iş birliğine açık, uysal, yumuşak başlı, diğerlerinin gereksinimlerini karşılamaya odaklı kişiler olduğu belirtilmektedir. Bu özelliğe sahip kişiler çevrelerince de sevilmektedir. Bu özelliklerinden dolayı uyumluluk kişilik özelliğine sahip kişilerin normatif bağlılığının yüksek olması beklenirken, bu kapsamdaki hipotez doğrulanmamıştır. Uyumlu kişilik özelliğine sahip bireyler için iş ortamının yorucu olduğu değerlendirilmektedir. Çünkü başkalarını düşünmek, diğerlerine yardımcı olmak ve kendi fikirlerini açıkça söyleyememek bu kişiler için sorun oluşturabilir.

Ayrıca bu kişilik özelliğine sahip kişilerin kariyer basamaklarında ilerleme konusunda uygun kişiler olarak değerlendirilmemesi ve diğer çal1şanlara göre daha az kazandığı ifade edilmektedir. Bu husus dikkate alındığında uyumlu kişilik özelliği ile normatif bağlılık arasında olumlu bir ilişki çıkmaması anlaşılabilir. Ancak kurallara uyan, yardımsever, insancıl olan bu kişilerin örgüte çok şey kazandıracağı muhakkaktır. Dolayısıyla bu kişilik özelliğine sahip bireylerin çoğunlukta olması, örgütün çıarına olacaktır. Bu bireylerin normatif bağlılığının artması yönetici ve iş arkadaşlarının da aynı özelliklere sahip olmasına bağlıdır. Ayrıca bu kişilerin performansının değerlendirilmesinde; diğer insanlara yardımcı olma, diğerlerinin gereksinimine öncelik verme gibi özellikleri dikkate alınmalı, 
bu özelliklerinden dolayı takdir edilmeli, katkıları görülmeli, özellikle maddi anlamda eşit imkânlar sağlanmalıdır.

Yapılan bu araştırmanın boylamsal olmaması ve sadece bir sektörde çalışan işgörenleri kapsayacak şekilde yapılmış olması araştırmanın önemli kısıtlarındandır. Bu sebeple araştırmanın başka sektörlerde ve değişik zamanlarda elde edilen veriler ile yapılması durumunda bu çalışmada ulaşılan sonuçlardan farklı sonuçlar elde edilebilir. 
EXTENDED ABSTRACT

\title{
The Effect of Relationship with Co-Workers and Quality of Supervision on Normative Commitment: The Mediating Role of Agreeableness Personality Trait
}

\author{
Mustafa Bekmezci - İbrahim Sani Mert - Hakan Turgut
}

Toros University, Antalya Science University, Başkent University

Today, organizations need to have qualified people who are committed to their organizations to gain competitive advantage. Because, it is foreseen that the people committed to their organization will adopt the values and aims of the organization and will work harder to realize them. As a matter of fact, empirical researches have shown that people committed to the organization exhibit positive behaviors for their organization. Employees want to continue membership in the organization because they identify themselves with the organization and are afraid to lose what they have gained from the organization or because they wholeheartedly believe that what they do in the organization is correct and moral.

Organizational commitment has an impact on the identification of individuals with the organization. As a result of this, it is concluded that the employees don't want to leave their jobs. There are personal, organizational and external factors that affect organizational commitment. Particularly business environment, colleagues and management have a central role in organizational commitment. In this context, the management style of the managers, the way the rules are applied, whether they behave fairly and the attitudes and behaviors of the colleagues are important. Satisfaction from management and colleagues reveals the employees' gratitude towards managers and colleagues. That is why employees see staying in the organization as a moral responsibility. On the other hand, it is thought that personality, which constitutes the basic structure of human behavior, covers how people react to events and how they can interact with other people. 
Accordingly, many scientists and practitioners agree on the importance of personality variables in predicting behavioral responses to working conditions. Although the five-factor personality traits model has been investigated in many areas of industrial organizational psychology, the relationship between this model and job satisfaction has been less studied. In this context, it can be said that employees who are more loved, more collaborative, friendly and trustworthy are defined as having a more normative commitment to managers and colleagues.

In this study, the effect of satisfaction with colleagues and management on normative commitment was investigated. In addition, it has also been investigated whether agreeableness personality trait plays a mediating role in this effect. The research was conducted on private hospital employees operating in Mersin.

When the results of the study were examined, a positive and significant relationship was found between satisfaction with colleagues and normative commitment, a positive and significant relationship between satisfaction with management and normative commitment, and a positive and significant relationship between agreeableness personality trait and satisfaction from colleagues. Contrary to expectations, it was found that normative commitment did not play a mediating role in the satisfaction of the colleagues and the satisfaction of the management.

Research has shown that there is a positive and significant relationship between job satisfaction and organizational commitment. Satisfaction from colleagues and satisfaction from management are sub-dimensions of job satisfaction. Therefore, satisfaction from colleagues and satisfaction from management is expected to have a positive effect on normative commitment and this result was obtained as a result of the research.

In the literature, it is stated that people with an agreeableness personality trait are helpful, reliable, humane and compassionate, think others, open to cooperation, docile and focused on meeting the needs of others. People with this feature are also loved by other employees. While the normative commitment of people with agreeableness personality trait is expected to be high due to these features, the hypothesis in this scope has not been verified. It is considered that the work environment is exhausting for individuals with agreeableness personality trait. Because thinking 
about others, helping others, and not being able to say their own ideas openly can be a problem for them.

It is also stated that people with this personality trait are not considered to be suitable persons in terms of progress on the career steps and earn less than other employees. Considering this, it is understandable that there is no positive relationship between this personality trait and normative commitment. However, it is certain that these people who follow the rules and are helpful and humane will contribute a lot for the organization. Therefore, it would be in the interest of the organization to have the majority of individuals with this personality trait. The increase of normative commitment of these individuals depends on the same characteristics of managers and colleagues. In addition, the characteristics of these people, such as assisting other people, giving priority to the needs of others, should be considered, appreciated for their characteristics, their contributions should be seen and equal opportunities should be provided in particular.

\section{Kaynakça / References}

Aslan, E. ve Kılıçlar, A. (2018). Otel işletmelerinde çalışanların kişilik özellikleri ile örgütsel bağlllıkları arasındaki ilişkide iş tatmininin aracilık rolü. Journal of Tourism and Gastronomy Studies, 6(4), 360375.

Agho, A.O., Mueller, C.W. ve Price, J.L. (1993). Determinants of employee job satisfaction: An empirical test of a causal model. Human Relations, 46(8), 1007-1027.

Allen, N.J. ve Meyer, J.P. (1990). The measurement and antecedents of affective, continuance and normative commitment to the organization. Journal of Occupational Psychology, 63, 1-18.

Aşan, Ö. ve Erenler, E. (2008). İş tatmini ve yaşam tatmini ilişkisi. Süleyman Demirel Üniversitesi İktisadi ve İdari Bilimler Dergisi, 13(2), 203-216.

Attio, S., Wahid, S., Javaid, N., Kanwal, M. ve Shah, H.J. (2017). The impact of employees' core self-evaluation, personality trait, management support, co-worker support on job satisfaction, and innovative work behavior. Pakistan Journal of Psychological Research, 32(1), 247271. 
Baron, R.M. ve Kenny, D.A. (1986). The moderator mediator variable distinction in social psychological research: Conceptual, strategic, and statistical considerations. Journal of Personality and Social Psychology, 51, 1173-1182.

Bono, J.E. ve Judge, T.A. (2004). Personality and transformational and transactional leadership: A meta-analysis. Journal of Applied Psychology, 89(5), 901-910.

Bulut, M.B. (2017). Akademisyenlerin örgütsel bağlılıkları, kişilik özellikleri ve tükenmişlik düzeyleri arasındaki ilişkiler. Uluslararası Sosyal Araştırmalar Dergisi, 10(50), 362-370.

Crossman, A. ve Abou-Zaki, B., (2003) Job satisfaction and employee performance of Lebanese banking staff. Journal of Managerial Psychology, 18(4), 368-376.

Çekmecelioğlu, H.G. (2005). Örgüt ikliminin iş tatmini ve işten ayrılma niyeti üzerindeki etkisi: Bir araştırma. Cumhuriyet Üniversitesi İktisadi ve İdari Bilimler Fakültesi Dergisi, 6(2), 23-39.

Çelik, M. ve Yıldız, B. (2018). Hemşirelerde mesleki bağlılık, özdeşleşme ve işten ayrilma niyeti ilişkisi: Kamu sektörü ve özel sektör karşılaştırması. Kastamonu Üniversitesi, İktisadi ve İdari Bilimler Fakültesi Dergisi, 20(2) 47-75.

Çetin, F. ve Basım, H.N. (2011). Psikolojik dayanıklılığın iş tatmini ve örgütsel bağlllık tutumlarındaki rolü. İş, Güç Endüstri İlişkileri ve Insan Kaynaklarn Dergisi, 13(3), 81-94.

Demir, C. (2012). Kişilik özellikleri ve iş tatmini arasındaki ilişkiyi belirlemeye yönelik bir uygulama, Yayımlanmamış Yüksek Lisans Tezi, İnönü Üniversitesi Sosyal Bilimler Enstitüsü İşletme Anabilim Dalı Yönetim ve Organizasyon Bilim Dalı, Malatya.

Digman, J. M. (1989). Five robust trait dimensions: development, stability, and utility, Journal of Personality, 57, 195-214.

Doğar, N. ve Gürsoy, A. (2017). Kişilikle örgütsel bağlllık arasındaki ilişki ve bu ilişkide iş tatmininin aracılık etkisi. Kara Harp Okulu Bilim Dergisi, 27(1), 113-146.

Doğan, S. ve Kılıç, S. (2007). Örgütsel bağlılığın sağlanmasında personel güçlendirmenin yeri ve önemi. Erciyes Üniversitesi İktisadi ve İdari Biimler. Fakültesi Dergisi, 29, 37-61. 
Dole, C. ve Schroeder, R.G. (2001). The impact of various factors on the personality, job satisfaction and turnover intentions of professional accountants. Managerial Auditing Journal, 16(4), 234-245.

Erdil, O., Keskin, H., İmamoğlu, S.Z. ve Erat, S. (2004). Yönetim tarzı ve çalışma koşulları, arkadaşlık ortamı ve takdir edilme duygusu ile iş tatmini arasındaki ilişkiler: Tekstil sektöründe bir uygulama. Doğuş Üniversitesi Dergisi, 5(1), 17-26.

Ergin, C. (1997). Bir iş doyumu ölçümü olarak iş betimlemesi ölçeği: Uyarlama, geçerlik ve güvenilirlik çalışması. Türk Psikoloji Dergisi, 12(39), 25-36.

Fand, Y. (2001). Turnover propensity and its causes among Singapore nurses: An empirical study. International Journal of Human Resource Management, 12, 859-877.

Freeborn, D.K. (1998). Satisfaction, commitment, and psychological wellbeing among HMO physicians. The Permanente Journal, 2(2), 22-30.

Friday, S.S. ve Friday, E. (2003). Racioethnic perceptions of job characteristics and job satisfaction. Journal of Management Development, 22(5), 426-442.

Goldberg, L.R. (1992). International Personality Item Pool, 12.07 .2018 tarihinde http://ipip.ori.org adresinden erişilmiştir.

Gordon, V. (2011). Exploring the job satisfaction of municipal clerks. Review of Public Personnel Administration, 31(2), 190-208.

Hatipoğlu, Z. ve Dündar, G . (2018). Örgütsel bağlılık ve iş tatmini arasındaki ilişkinin $X$ ve $Y$ kuşaklarına göre farklılıklarının incelenmesi. Yorum Yönetim Yöntem Uluslararası Yönetim Ekonomi ve Felsefe Dergisi, 6(2), 43-56.

Hodgetts, R.M., (1991). Organisational behaviour: Theory and practice. USA: Maxwell Macmillan International Publishing Group.

Hogan, J. ve Kaiser, R.B. (2005). What we know about leadership? Review of General Psychology, 9(2), 169-180.

Hoş, C. ve Oksay, A. (2015). Hemşirelerde örgütsel bağlllık ile iş tatmini ilişkisi. Süleyman Demirel Üniversitesi İktisadi ve İdari Bilimler Fakültesi Dergisi, 20(4), 1-24. 
Ishfaq, A. ve Usman, R.S.L. (2011). Jobs satisfaction mediates relationship between facets of job and citizenship behavior: A study of female employees of banking sector of Pakistan. Information Management and Business Review, 3(4), 228-234.

İnce, M. ve Gül, H. (2005). Örgütsel bağhllık. Ankara: Çizgi. İnceoğlu, M. (2004). Tutum, algı, iletişim. Ankara: Elips.

İşçan, Ö.F. ve Timuroğlu, M.K. (2007). Örgüt kültürünün iş tatmini üzerindeki etkisi. İktisadi ve İdari Bilimler Dergisi, 21(1), 119-135.

Jong, R.D.D., van der Velde, M.E.G. ve Jansen, P.G.W. (2001). Openness to experience and growth need strength as moderators between job characteristics and satisfaction. International Journal of Selection and Assessment, 9(4), 350-356.

Judeg, T.A., Thoresen, C.J., Bono, J.E. ve Patton, G.K. (2001). The job satisfaction-job performance relationship: A qualitative and quantitative review. Psychological Bulletin, 127(3), 376-407.

Lam, S.S.K. (1995). Quality management and job satisfaction: An empirical study. International Journal of Quality \& Reliability Management, 12(4), $72-78$.

Lim, S. (2008). Job satisfaction of information technology workers in academic libraries. Library and Information Science Research, 30(2), 115121.

Limpanitgul, T., Boonchoo, P. ve Photiyarach, S. (2014). Coworker support and organisational commitment: A comparative study of Thai employees working in Thai and American airlines. Journal of Hospitality and Tourism Management, 21, 100-107.

Luthans, F. (2005). Organisational behavior. New York: McGraw-Hill.

Mcdonald, D.J. ve Makin, P.J. (2000). The psychological contract, organisational commitment and job satisfaction of temporary staff. Leadership \& Organization Development Journal, 21(2), 84-91.

Meyer, J.P. ve Allen, N.J. (1991). A three-component conceptualization of organizational commitment. Human Resources Management Review, 1, 61-89.

Meyer, J.P., Allen, N.J. ve Smith, C.A. (1993). Commitment to organizations and occupations: Extension and test of a three-component conceptualization. Journal of Applied Psychology, 78, 538-551. 
Miller, K.I. ve Monge, P.R. (1986). Participation, satisfaction and productivity: A meta-analytic review. Academy of Management Review, 29(4), 727-753.

Moorman, R.H. (1993). The influence of cognitive and affective based job satisfaction measures on the relationship between satisfaction and organizational citizenship behavior. Human Relations, 46(6), 759776.

Ocak, S., Gider, Ö., Gider, N. ve Top, M. (2017). Kişilik özelliklerinin örgütsel bağlllık ve örgütsel özdeşleşme üzerinde etkileri: Bir kamu hastanesi örneği. İstanbul Üniversitesi İşletme Fakültesi İşletme İktisadı Enstitüsü Yönetim Dergisi, 82, 105-126.

Oshagbemi, T. (2000). Satisfaction with co-worker's behavior. Employee Relations, 22(1), 88-106.

Özkalp, E. ve Kırel, Ç. (2001). Örgütsel davranış. Eskişehir: Anadolu Üniversitesi Yayınları.

Panaccio, A. ve Vandenberghe, C. (2012). Five-factor model of personality and organizational commitment: The mediating role of positive and negative affective states. Journal of Vocational Behavior, 80, 647658.

Porter, L.W., Steers, R.M. ve Mowday, R.T. (1974). Organizational commitment, job satisfaction, and turnover among psychiatric technicians. Journal of Applied Psychology, 59(5), 603-609.

Recepoğlu, E., Kılınç, A.Ç., Şahin, F. ve Er, E. (2013). Öğretim elemanlarının kişilik özellikleri ile örgütsel bağlılık düzeyleri arasındaki ilişki. Turkish Studies-International Periodical for the Languages, Literature and History of Turkish or Turkic, 8(6), 603-617.

Richards, B., O'Brien, T. ve Akroyd, D. (1994). Predicting the organizational commitment of marketing education and health occupations education teachers by work related rewards. JITE, 32(1). 01 Aralık 2010 tarihinde http://scholar.lib.vt.edu/ejournals/JITE/v32n1/Richards.html adresinden erişilmiştir.

Robbins, S.P. ve Judge, T.A. (2012). Örgütsel davranış. (İ. Erdem Ed.), Ankara: Nobel.

Savery, L.K., (1996). The congruence between the importance of job satisfaction and the perceived level of achievement. Journal of Management Development, 15(6), 18-27. 
Schneider, B. ve Dachler, H.P. (1978). A note on the stability of the job descriptive index. Journal of Applied Psychology, 63, 650-653.

Sekaran, U. (1992). Research methods for business. Canada: John Wiley\&Sons.

Sığrı, Ü. ve Basım, N. (2006). İşgörenlerin iş doyumu ile örgütsel bağlılık düzeylerinin analizi: Kamu ve özel sektöründe karşılaştırmalı bir araştırma. SÜ İ̈BF Sosyal ve Ekonomik Araştırmalar Dergisi, 131-154. 13.02.2019 tarihinde http://dergipark.gov.tr/download/articlefile/289524 adresinden erişilmiştir.

Steers, R.M. (1991). Introduction to organisational behavior. (4th Ed.), USA: Harper Collins Publishers Inc.

Sullivan, S.E. ve Baghat, R.S. (1992). Organizational stress, job satisfaction, and job performance: Where do we go from here? Journal of Management, 18(2), 353-375.

Tabak, A., Şeşen, H. ve Türköz, T. (2012). Liderlikte güncel konular. Ankara: Detay Yayıncilik.

Tatar, A. (2017). Büyük beş kişilik testinin Türkçe'ye çevirisi ve beş faktör kişilik envanteri kısa formu ile karşılaştırılması. Anadolu Psikiyatri Dergisi, 18(1), 51-61.

Tella, A., Ayeni, C.O. ve Popoola, S.O. (2007). Work motivation, job satisfaction and organizational commitment of library personnel in academic and research libraries in Oyo state, Nigeria. Library Philosophy and Practice, 1-16.

Wasti, S.A. (2000). Meyer ve Allen'in üç boyutlu örgütsel bağlllık ölçeğinin geçerlilik ve güvenilirlik analizi, 8. Ulusal Yönetim ve Organizasyon Kongresi, 25-27 May1s, Kayseri, 401-410.

Wasti, S.A. (2003). Organizational commitment, turnover intentions and the influence of cultural values. Journal of Occupational and Organizational Psychology, 76, 303-321.

Yang, X. ve Wang, W. (2013). Exploring the determinants of job satisfaction of civil servants in Beijing, China. Public Personnel Management, 42(4), 556-587.

Yeşil, S. ve Dereli, S.F. (2012). Örgütsel adalet ve iş tatmini üzerine bir alan çalışması. Sütçü İmam Üniversitesi İktisadi ve İdari Bilimler Fakültesi Dergisi, 2(1), 105-122. 
Yılmaz, K. (2012). İlköğretim okulu öğretmenlerinin iş doyumu düzeyleri ile örgütsel vatandaşlık davranışları arasındaki ilişki. Anadolu Journal of Educational Sciences International, 2(2), 1-14.

\section{Kaynakça Bilgisi / Citation Information}

Bekmezci, M., Mert, İ.S. ve Turgut, H. (2019). İş arkadaşlarından ve yönetimden duyulan tatminin normatif bağlılığa etkisi: Kişilik özelliklerinden uyumluluğun aracılık rolü. OPUS-Uluslararası Toplum Araştırmaları Dergisi, 12(18. UіKK Özel Sayısı), 607-633. DOI: 10.26466-/opus.590495 